\title{
REFLECTIONS ON RICARDIAN \\ EQUIVALENCE
}

Robert J. Barro

Working Paper 5502

NATIONAL BUREAU OF ECONOMIC RESEARCH

1050 Massachusetts Avenue

Cambridge, MA 02138

March 1996

This paper is part of NBER's research programs in Economic Fluctuations and Growth, and Public Economics. Any opinions expressed are those of the author and not those of the National Bureau of Economic Research.

(C) 1996 by Robert J. Barro. All rights reserved. Short sections of text, not to exceed two paragraphs, may be quoted without explicit permission provided that full credit, including $\odot$ notice, is given to the source. 


\title{
REFLECTIONS ON RICARDIAN \\ EQUIVALENCE
}

\begin{abstract}
The Ricardian equivalence proposition for public debt in my 1974 JPE paper is related to the discussions in Ricardo's Funding System, Smith's Wealth of Nations, and a number of treatments in macroeconomics from the 1950s to the 1970s. Useful extensions of the basic invariance proposition involve tax smoothing (in the context of distorting taxation) and the determinants of the maturity and other characteristics of the debt structure (in an environment of uncertainty).
\end{abstract}

Robert J. Barro

Department of Economics

Littauer Center 120

Harvard University

Cambridge, MA 02138

and NBER 
I have three excuses for writing a paper about the origins of my work on Ricardian equivalence. First, admittedly thin, is that the organizer of a conference asked me to do it. Second, I have a number of anecdotes on the topic that I would like to write down. Third, my 1974 JPE paper, "Are Government Bonds Net Wealth?," has thus far been cited, as a rough guess, 840 times, which is approximately 348 more times than my next most cited work (a paper on unanticipated money in the $1977 A E R$ ). This unusual level of attention suggests that someone might be interested in these thoughts.

There are, of course, compelling arguments on the other side. A paper of this sort is inevitably pretentious. Moreover, as my son Jason pointed out, one tends to write this type of piece toward the end of a career when more serious uses of time are unavailable. Thus, there is some inconsistency with my pretense toward maintaining a high current level of research productivity. Nevertheless, I have obviously decided to go ahead.

I recall a discussion with Gary Becker soon after my arrival as a junior faculty member in Chicago in 1972. He asked about the state of macroeconomics, and I replied that the field was stagnating. I mentioned that I was finishing some research on Keynesian economics, a field that I regarded as a dead end, and planned to switch my main research efforts to microeconomic topics. This assessment was offered just before I began work on the economics of public debt and-shortly thereafter-on theoretical and empirical work related to rational expectations. Thus, I was not a good predictor either of the Bob Lucas led rational expectations revolution-which was soon to energize macroeconomics—or of my own research path.

I cannot recall the precise inspiration for the model of intergenerational altruism in my 1974 paper. I know that I was dissatisfied with the standard assumption that people felt wealthier if the public debt were expanded, and this condition seemed to entail a 
neglect of the taxes needed to pay future interest and principal. It also seemed natural to address this matter within the overlapping-generations framework of Samuelson (1958) and Diamond (1965), a setting in which the interactions between members of adjacent generations could be studied.

It was only later that I recognized the connections of my analysis with Gary Becker's research on interactions among family members. Once this connection became clear, George Stigler-then my co-editor of the Journal of Political Economyproposed that Gary's paper on social interactions appear together with mine in the November/December 1974 issue of the journal. (As I recall, it was my idea to violate alphabetical order and have Gary's paper come first with mine second.)

In terms of time devoted to formal modeling and writing, my 1974 paper is probably the quickest article that I have ever produced. 1 Before I wrote anything, I spent time thinking about the basic invariance proposition for intergenerational transfers- the idea that the government's transfers implied by budget deficits or pay-asyou-go social security would be fully undone if family members were connected through voluntary transfers based on altruism. It was then immediate, in a basic framework, that budget deficits or social security would not matter for key macroeconomic variables, such as real interest rates and the quantity of investment.

I went through the central argument in 1973 during a lunch in Chicago with Fischer Black, who was then on the faculty of Chicago's business school. I stressed that the result required only an interior solution for private intergenerational transfers; the volume of transfers did not have to be large. My recollection is that Fischer just

1Perhaps I wrote it too fast, because a job-market candidate (who did not receive an offer) once told me that the paper was too long and that the argument could have been made much more concisely. My paper on rules versus discretion with David Gordon in the 1983 $J P E$ may have been produced more rapidly. In that case, I was inspired by David's job-market seminar at Rochester and pretty much wrote up my contribution to the article the next day on a plane trip to Boston. But the comparison is unfair because David had already spent a good deal of time on the ideas. 
listened while I took about 10 minutes to go through the analysis. I will never forget his response: "Sounds right to me."

I remember giving seminars on my 1974 paper only twice. The first was a wondrous session of Chicago's money workshop, the only one I know of that was attended simultaneously by the great trio of Gary Becker, Milton Friedman, and George Stigler. It was the first time that I noticed Milton being impressed with something I had written. It was also the first time that I thought I won an argument with Gary. (It concerned my contention, I believe correct, that the invariance result went through in the presence of inheritance taxes as long as an interior solution for private transfers still applied. At one point, Milton put his head down in deep thought for a couple minutes and then finally concluded that I was right. It also seemed that Milton was quite surprised at the notion that Gary would therefore be wrong.)

With hindsight, the most surprising aspect of the seminar is that nobody, including me, mentioned the relation of my analysis to the work of David Ricardo. My excuse for being blissfully ignorant in 1973 of Ricardo's contribution is that I was a young, non-tenured faculty member with inadequate graduate training from Harvard University. But I have always been puzzled that George Stigler did not mention the connection with Ricardo; he could have saved me from embarrassment later on.

The second seminar also took place in Chicago, but at the business school. It was hard in this case to get beyond page one, because Gene Fama kept arguing that the government's decisions on debt and taxes were obviously inconsequential because private financial markets were efficient. I finally said that my model presented conditions under which budget deficits did not matter. Gene regarded this irrelevance proposition as a worthy objective, so he allowed me to proceed without further interference. (I suppose it is no accident that Ricardian equivalence-the public-sector 
analog to the Modigliani/Miller [1958] theorem-appeals much more readily to finance specialists than to macroeconomists.)

The term Ricardian equivalence is now familiar even to undergraduate students of macroeconomics, but such was not the case in 1974. I did not learn of my implicit intellectual debt to Ricardo until Jim Buchanan wrote his comment, "Barro on the Ricardian Equivalence Theorem," which appeared in the 1976 JPE. Jim referred to the discussion in The Principles of Political Economy and Taxation, first published in 1817, but Gerald O'Driscoll pointed out in his 1977 JPE paper that a fuller treatment is in Ricardo's Funding System, ${ }^{2}$ which appeared in 1820 as an article in the supplement to the Encyclopedia Britannica. This essay suggests that the invariance proposition goes through with finite lifetimes as long as people plan to leave bequests to their descendants. The argument, some of which appeared earlier in the Principles, is as follows:
"Suppose a country to be free from debt, and a war to take place, which should involve it in an annual additional expenditure of twenty millions, there are three modes by which this expenditure may be provided; first, taxes may be raised to the amount of twenty millions per annum, from which the country would be totally freed on the return of peace; or, secondly, the money might be annually borrowed and funded; in which case, if the interest agreed upon was 5 per cent., a perpetual charge of one million per annum taxes would be incurred for the first year's expence, from which there would be no relief during peace, or in any future war; of an additional million for the second year's expence, and so on for every year that the war might last. At the end of twenty years, if the war lasted so long, the country would be perpetually encumbered with taxes of twenty millions per annum, and would have to repeat the same course on the recurrence of any new war. The third mode of providing for the expences of the war would be to borrow annually the twenty millions required as before, but to provide, by taxes, a fund, in addition to the interest, which, accumulating at compound interest, should finally be equal to the debt. In the case supposed, if money was raised at 5 per

${ }^{2}$ Funding System has apparently not always been held in high esteem. In the introduction to a collection of Ricardo's essays published in 1923, the editor, E.C.K. Gonner, says that his book "contains the five important pamphlets published by Ricardo, the only economic writings omitted being the two entitled respectively Plan for a National Bank and Essay on the Funding System, both of which are ephemeral in their interest and neither of which seems to call for reproduction." Probably Professor Gonner would also have thought little of my work on Ricardian equivalence. 
cent., and a sum of $200,000 £$ per annum, in addition to the million for interest were provided, it would accumulate to twenty millions in 45 years; and by consenting to raise $1,200,000 £$ per annum by taxes, for every loan of twenty millions, each loan would be paid off in 45 years from the time of its creation; and in 45 years from the termination of the war, if no new debt were created, the whole would be redeemed, and the whole of the taxes would be repealed.

...In point of economy, there is no real difference in either of the modes; for twenty millions in one payment, one million per annum for ever, or $1,200,000 £$ for 45 years, are precisely of the same value ... It would be difficult to convince a man possessed of $20,000 £$, or any other sum, that a perpetual payment of $50 £$ per annum was equally burdensome with a single tax of $1000 £$. He would have some vague notion that the $50 £$ per annum would be paid by posterity, and would not be paid by him; but if he leaves his fortune to his son, and leaves it charged with this perpetual tax, where is the difference whether he leaves him 20,000£, with the tax, or 19,000£ without it? This argument of charging posterity with the interest of our debt, or of relieving them for a portion of such interest, is often used by otherwise well informed people, but we confess we see no weight in it." (Ricardo [1951b, pp. 185-187], italics added)

My initial reaction to Jim Buchanan's mention of my failure to cite Ricardo was that economists sometimes try too hard to read modern results into the writings of their ancestors. Moreover, I figured that it would be easy to find the essence of the equivalence result in earlier writings, such as Adam Smith's Wealth of Nations. To my surprise, I found from a rereading of Smith that his analysis of fiscal policy was pretty garbled and surely inferior to Ricardo's. The same goes for other pre-Ricardian discussions of public debt that I examined, such as that by the French economist J.B. Say (1821). So I eventually decided that Ricardo deserved credit for the original idea and that Ricardian equivalence was a perfectly fine terminology.

David Hakes and Ken McCormick (1995) conclude instead that Adam Smith understood Ricardian equivalence perfectly well before Ricardo. The first part of the discussion that they cite from Smith (1790, pp. 424-426) is as follows:

"The public funds of the different indebted nations of Europe, particularly those of England, have by one author been represented as the accumulation of a great capital superadded to the other capital of the country ... He does not consider that the capital which the first creditors of the public advanced to government, was, from the moment in which they advanced it, a certain portion of 
the produce turned away from serving in the function of a capital, to serve in that of a revenue; ... In return for the capital they advanced, they obtained, indeed, an annuity in the public funds in most cases of more than equal value. This annuity, no doubt, replaced to them their capital, and enabled them to carry on their trade and business to the same or perhaps to a greater extent than before; that is, they were enabled either to borrow of other people a new capital upon the credit of this annuity, or by selling it to get from other people a new capital of their own, equal or superior to that which they had advanced to government. This new capital, however, which they in this manner either bought or borrowed of other people, must have existed in the country before ... When it came into the hands of those who had advanced their money to government, though it was in some respects a new capital to them, it was not so to the country; ... Though it replaced to them what they had advanced to government, it did not replace it to the country."

It may be a weakness in my intelligence, but I find this passage incoherent. In particular, it is unclear whether "capital" refers to financial assets or to a cumulated stock of productive goods, a distinction that matters when the quantity of public debt varies. The economic influence of government spending is also not distinguished from that of alternative methods of finance. Hence, the analysis provides no indication as to what forms of private behavior would cause macroeconomic variables such as investment and real interest rates to be invariant with the choice between debt and taxes.

In subsequent passages, Smith (1790, pp. 426-7) discusses the responses of private saving to alternative forms of public finance:

"When for defraying the expence of government a revenue is raised within the year from ... taxes ... Some part of what they pay in those taxes might no doubt have been accumulated into capital, ... but the greater part would probably have been spent ... The public expence, however, when defrayed in this manner, no doubt hinders more or less the further accumulation of new capital; but it does not necessarily occasion the destruction of any actually existing capital.

When the public expence is defrayed by funding, it is defrayed by the annual destruction of some capital which had before existed in the country; ... As in this case, however, the taxes are lighter than they would have been, had a revenue sufficient for defraying the same expenditure been raised within the year; the private revenue of individuals is necessarily less burdened, and consequently their ability to save and accumulate some part of that revenue into capital is a good deal less impaired. If the method of funding destroy more old capital, it at the same time hinders less the accumulation or acquisition of new capital, than that of defraying the public expence by a revenue raised within the year. Under 
the system of funding, the frugality and industry of private people can more easily repair the breaches which the waste and extravagance of government may occasionally make in the general capital of the society."

I find it hard to discern here whether Smith thinks that domestic investment and national saving will rise or fall if taxes are replaced by borrowing. Nor is it clear whether there exists a pattern of private behavior that would make the two modes of finance equivalent. In any event, the contrast between Smith's flawed discussion and Ricardo's clear analysis, as cited above, makes it apparent that the equivalence theorem is far more Ricardian than Smithian.

Even abstracting from Ricardo's contributions, there were some macroeconomic articles of the 1950s and 1960s which (while not mentioning Ricardo) observed that standard analyses of fiscal policy neglected the wealth implications from the government's future payments of interest and principal. In my 1974 paper, I referenced an observation made in 1952 by $\operatorname{Jim}$ Tobin $(1971$, p. 91):

"How is it possible that society merely by the device of incurring a debt to itself can deceive itself into believing that it is wealthier? Do not the additional taxes which are necessary to carry the interest charges reduce the value of other components of private wealth?"

Similarly, I referred to Martin Bailey's (1962, pp. 75-77) more detailed discussion:

"... it is possible that households regard deficit financing as equivalent to taxation. The issue of a bond by the government to finance expenditures involves a liability for future interest payments and possible ultimate repayment of principle, and thus implies future taxes that would not be necessary if the expenditures were financed by current taxation. If a typical household were to save the entire amount that was made available to it by a switch from current taxation to deficit financing, the interest on the saving would meet the future tax charges to pay interest on the government bonds, while the principal saved would be available to meet possible future taxes imposed to repay the principal of the government bonds.* ( ${ }^{*}$ The same argument applies if no repayment is expected, if the typical household plans to leave an estate of definite net income potential after taxes, for 
given alternatives available and given current weal th position.) ... If future tax liabilities implicit in deficit financing are accurately foreseen, the level at which total tax receipts are set is immaterial; the behavior of the community will be exactly the same as if the budget were continuously balanced."

Aside from Bailey's footnote about estates (which I had overlooked in my 1974 paper), these points did not consider the role of finite lifetimes and the notionexpressed in Ricardo's Funding System - that the equivalence result could still hold in this setting because of the adjustment of private intergenerational transfers. When I was working on this idea, I was unaware that a related point was raised in a paper that Bob Hall wrote in 1967 as an MIT graduate student but neither circulated nor published (until 1990). Bob argued that that the public debt may not matter because of the endogeneity of inheritance: ${ }^{3}$

"... in this model the equilibrium is independent of the size of the government's debt, so there is no burden of the debt. In Diamond's [1965] model, the equilibrium is sensitive to the size of the debt because the market capitalizes all of the interest payments which a bond yields but the individual takes account of only the tax payments to finance the interest which are levied during his lifetime. This asymmetric effect makes him spend more and save less, driving up the interest rate. Under the inheritance hypothesis there is no asymmetry because the individual does not distinguish between his own wealth and the wealth of the future generations of his family. The equilibrium is independent of any transfer of wealth between generations and in particular is independent of the transfer implied by taxing and paying interest." (Hall [1990, p. 18])

Bob told me that he did not pursue this idea because his adviser, Peter Diamond, told him that the point was obvious, of no practical significance, and surely not worth Bob's research time. (Peter told me that he has since become more cautious in offering advice to students.) Bob also said that he had lost all copies of the paper but that his fellow graduate student, Joe Stiglitz, happened to find a copy many years later.

${ }^{3}$ The role of a bequest motive in eliminating the net wealth effect of government bonds was also discussed by Miller and Upton (1974, pp. 176-79). I recall Charles Upton expressing regret that Feldstein's (1976) comment was directed at my paper rather than his book. 
In preparing my rejoinder to Jim Buchanan's 1976 comment, I was disappointed when he deleted from his first version a point that I thought was flawed and therefore an easy target for a response. (He had argued initially that Ricardian equivalence was impossible purely as a matter of logic.) But Marty Feldstein retained a wonderful non sequitur that I have since found useful for exam problems. His argument was that Ricardian equivalence necessarily failed if the economy were growing at a positive rate. Letting $g$ be the growth rate and $r$ the real interest rate, he said:

" if ... the debt grow[s] at the rate of growth of the economy, taxes will be required to finance only the fraction $(1-\mathrm{g} / \mathrm{r})$ of future interest payments ... only in the special case of a static economy $(g=0)$ is the present value of required future taxes equal to the present value of the debt itself." (Feldstein [1976, pp. 332-33])

The fallacy, of course, is that the fraction $(1-\mathrm{g} / \mathrm{r})$ applies to a base that is larger, increasingly over time, than it would have been if the debt had remained constant rather than growing at the rate $\mathrm{g}$. In this context, the only condition needed to ensure Ricardian equivalence is that Ponzi games be precluded; that is, the real debt must grow asymptotically at a rate lower than the real rate of return on capital.

In his $1977 J P E$ paper, Gerald O'Driscoll made a lot out of the idea that Ricardo doubted the empirical relevance of his famous theorem. Ricardo, in the quote cited before from Funding System (pp. 186-7), outlined three alternative modes of paying for wartime spending - taxes, borrowing, and borrowing with the establishment of a sinking fund-and then said:

"Of these three modes, we are decidedly of the opinion that the preference should be given to the first. The burthens of the war are undoubtedly great during its continuance, but at its termination they cease altogether. When the pressure of the war is felt at once, without mitigation, we shall be less disposed wantonly to engage in an expensive contest, and if engaged in it, we shall be sooner disposed to get out of it, unless it be a contest for some great national interest. In point of 
economy there is no real difference in either of the modes ... but the people who pay the taxes never so estimate them, and therefore do not manage their private affairs accordingly. We are too apt to think, that the war is burdensome only in proportion to what we are at the moment called to pay for it in taxes, without reflecting on the probable duration of such taxes. It would be difficult to convince a man possessed of $20,000 \mathcal{E}$, or any other sum, that a perpetual payment of $50 \AA$ per annum was equally burdensome with a single tax of $1000 £$. ... That an annual tax of $£ 50$ is not deemed the same in amount as $£ 1000$ ready money, must have been observed by every body. If an individual were called upon to pay $£ 1000$ to the income-tax, he would probably endeavour to save the whole of it from his income; he would do no more if, in lieu of this war-tax, a loan had been raised, for the interest of which he would have been called upon to pay only $£ 50$ income-tax. The war-taxes then are more economical; for when they are paid, an effort is made to save to the amount of the whole expenditure of the war, leaving the national capital undiminished. In the other case, an effort is only made to save to the amount of the interest of such expenditure, and therefore the national capital is diminished in amount."

Despite this lapse, Ricardo deserves credit for the theorem that, under rational behavior, debt and taxes would be regarded as equivalent. He should perhaps be forgiven for harboring the heretical belief that people would not act in accordance with the assumptions of his theorem; that is, that they would not act fully "in point of economy" (meaning rationally?).

Although the correct parts of Ricardo's argument cannot be found in Smith, some of the lapses seem to be there. Specifically, on the matter of paying for wars with taxes, Smith (1790, p. 427) said:

"Were the expence of war to be defrayed always by a revenue raised within the year, the taxes from which that extraordinary revenue was drawn would last no longer than the war. ... Wars would in general be more speedily concluded, and less wantonly undertaken. The people feeling, during the continuance of war, the complete burden of it, would soon grow weary of it, and government, in order to humour them, would not be under the necessity of carrying it on longer than it was necessary to do so."

Thus, it seems that Ricardo borrowed this dubious argument from Smith without subjecting it to careful analysis. 
The familiarity of Ricardian equivalence today can be demonstrated by an experience that I had while working with a Boston attorney on a consulting case. I went one weekend to the lawyer's office and was met by a security guard, who asked me to sign the register. After going upstairs and working for a couple hours, I returned to the guard's desk downstairs. He had apparently noticed my name on the register and asked, "Are you the Barro who works on Ricardian equivalence?" (It probably ruins the story to mention that the guard happened to be a moonlighting graduate student in economics from Boston University.)

Needless to say, Ricardian equivalence is not always held in high repute by macroeconomists or the popular press. For example, Peter Passell of The New York Times once quoted Robert J. Gordon to the effect that Ricardian equivalence was an "aerie fairy theory." I was unsure exactly what this phrase meant, but I suspected that it was not complimentary. So I decided to learn more by placing the following (extra credit) question on a graduate macroeconomics exam at Harvard: "The Ricardian view that budget deficits are irrelevant for the economy has been described as an 'aerie fairy' theory in The New York Times. What is the Ricardian view and what does aerie fairy mean?"

Herewith some of the better answers:

"I don't know what aerie fairy means. Nobody said that we would be tested on that."

"Aerie fairy could mean ... the author learned macroeconomics when the IS-LM model was in the unquestioned ascendancy ..."

"Aerie fairy seems to belittle the theory as the work of an academic scribbler out of touch with the realities of saving and investment."

"Aerie fairy probably means something like I don't know what the hell you're talking about, or, I, personally, never save to pay future taxes."

"Aerie fairy means he's a Keynesian and does not like Neoclassicals." 
"Aerie fairy would imply that the theory is devoid of any relevance, utterly out in space, of no bearing in the real world, and perhaps even nutty."

"Aerie fairy is essentially a meaningless pejorative term used by social commentators with leftist inclinations to dismiss sophisticated economic theories that they disagree with but cannot fully understand or refute."

"Aerie fairy means that The New York Times thinks this is weird and wrong."

"Just as some people believe in fairies, so might people believe in Ricardian equivalence."

"Aerie fairy means ... totally unrealistic, wishy washy, nonsense. No offense! Not that I agree..."

"Aerie fairy means in la la land, out of touch with the indisputable, hard facts of the world."

"I don't know what aerie fairy means, but I assume it's something good."

In my 1989 paper in the Journal of Economic Perspectives, I surveyed the theoretical objections that have been raised against Ricardian equivalence. The main areas involve the finiteness of life, imperfections of private credit markets, uncertainty about the incidence of future taxes and about other variables, and the distortionary nature of taxation. The incorporation of these features tends to generate results that are not strictly Ricardian, although the conclusions usually diverge also from those of standard analyses. Moreover, the quantitative significance of these departures from Ricardian equivalence is unclear.

I will not go into these objections to the Ricardian result in detail here, but my view is that the most important consideration is the distorting nature of real-world taxes. Budget deficits influence the timing of taxes, and this timing generally matters if the levies apply to labor income, consumption, and so on. People are motivated to earn labor income in periods of low labor tax rates and to consume in periods of low consumption tax rates. Hence, variations in the anticipated timing of these levies alters the intertemporal allocations of work effort and consumption. 
Since the time path of tax rates matters, it is possible to design a pattern of public debt issue to support a desired tax plan. That is, optimal debt management corresponds to the solution to an optimal-tax problem. In many cases, the optimal-tax criterion calls for tax rates to be smoothed over time. In particular, the rates levied on labor income or consumption (but not on capital income) should be roughly uniform, rather than varying dramatically from one period to the next.

My 1979 JPE paper worked out a simple version of this tax-smoothing idea. (Once again, I failed to credit my ancestors; in this case, A.C. Pigou for his 1928 study of public finance.) At one level, the framework provides a normative model of debt management. At another level, if the behavior of government conforms in some ways to an optimal-tax criterion, then the results constitute a positive theory of budget deficits. In this second context, the model can be tested empirically by seeing whether the government's choices accord with the theoretical predictions. This framework does well in some respects - for example, in accounting for the usual response of budget deficits to wars and recessions-but also leaves unexplained much of the observed variations in budget deficits over time and across countries.

More recently (in Barro [1995]), I have followed the analysis of Bohn (1990) and others to consider the optimal structure of public debt with respect to maturity and other characteristics. The general approach can be viewed in three stages.

First, if taxes are lump sum and the other conditions for Ricardian equivalence hold, then the division of government financing between debt and taxes is irrelevant, and the whole level of public debt is indeterminate from an optimal-tax standpoint. Second, if taxes are distorting, then the timing of taxes typically matters; for example, it may be desirable to smooth tax rates over time. If policymakers can make credible commitments, which overcome possible problems of time consistency, then this 
consideration makes determinate the levels of debt at various dates. However, this analysis is silent about the composition of the debt, say by maturity.

Finally, if there is uncertainty about real interest rates, levels of public outlay, GDP, and so on, then the relation of tax rates to states of nature becomes important. In some cases, optimal taxation dictates the smoothing of tax rates over states of nature, and this element may pin down the composition of the debt. For example, the maturity structure can be designed to insulate the government's financing costs from shifts in real interest rates. In a simple benchmark case, optimal debt management then entails the issue of indexed consols. That is, long-term indexed debt insulates the government's budget constraint from unpredictable fluctuations in real interest rates. (In contrast, if the government is forced for some reason to issue nominal bonds, then the uncertainty of inflation tends to make short maturities desirable.)

More generally, the real payouts on the public debt would also be designed to be contingent on the level of government outlays and the state of the economy. In particular, abstracting from moral-hazard problems related to the determination of government spending (and the waging of war), it would be desirable for the debt to pay poorly ten public outlays were high (as in war) and well when outlays were low (as in peace). This idea was pursued by Lucas and Stokey (1983), and Judd (1991) showed than an equivalent fiscal policy could be constructed by means of capital levies that absorbed the surprises in government spending.

Ricardo's Funding System should perhaps also be credited for these ideas. After arguing that wars ought to be financed by current taxation (as cited above), Ricardo said (pp. 188-9):

"These large taxes, it may be said, must fall on property ... Those who are in professions, as well as those who live from salaries and wages, and who now contribute annually to the taxes, could not make a large ready money payment; 
and they would, therefore, be benefited at the expence of the capitalist and landholder.

The greatest advantage that would attend war-taxes would be, the little permanent derangement that they would cause to the industry of the country. ... By war-taxes, we should save many millions in the collection of taxes. ... There would be no charges for the management of debt. ... In every view of this question, we come to the same conclusion, that it would be a great improvement in our system for ever to get rid of the practice of funding. Let us meet our difficulties as they arise, and keep our estates free from permanent encumbrances, of the weight of which we are never truly sensible, till we are involved in them past remedy."

McCulloch (1846, p. xxviii), although a great fan of Ricardo overall, was skeptical about the wisdom of the proposal for a capital levy in time of war:

"He [Ricardo] was a decided friend to the plans for raising the supplies for a war within the year, by an equivalent increase of taxation; and he also thought (in which opinion few probably will be disposed to concur) that it would be not only expedient but practicable to pay off the public debt by an assessment on capital."

Unfortunately, McCulloch did not detail the reasons for this criticism.

\section{Concluding observations}

The Ricardian equivalence theorem amounts to the statement that the government's fiscal impact is summarized by the path of its expenditures. Given this path, rearrangements of the timing of taxes-as implied by budget deficits-have no first-order impact on the economy. Second-order effects arise for various reasons, of which I have argued that the distorting effects of taxes are the most important. This consideration leads to the idea that tax rates on labor income and consumption ought to be smoothed over time and states of nature. 
Although the majority of economists still lean toward standard macroeconomic models of fiscal policy, it is remarkable how respectable the Ricardian approach has become. Most macroeconomists now feel obligated to state the possibility of Ricardian equivalence (often just to demonstrate some minimal level of economic competence), ${ }^{4}$ even if they then use models in which equivalence fails. One virtue of this situation is that non-equivalence has to be generated by the model rather than from an assumption that turns out to be inconsistent with the model.

In this respect, the role of the Ricardian equivalence theorem in public finance is analogous to that of the Modigliani-Miller (1958) theorem in corporate finance. In each case, the assumptions of the theorem are frequently thought to be unrealistic, but the recognition of the constraints of the theorem force analyses into internally consistent, productive modes. So, unlike some of my youthful research on Keynesian economics, I have never wished to recant any of my work on Ricardian equivalence.

4Unfortunately, there is a growing tendency for economists to mention Ricardian equivalence without offering an explicit citation to the literature, such as my $1974 J P E$ paper. Perhaps as a consequence, the annual cite count for my paper peaked at 85 in 1989 and has since fallen to 30 in 1994. Earlier the count seemed to get a substantial boost from President Reagan's budget deficits-the number of citations rose from an average of 30 per year for $1980-82$ to 69 for $1985-89$. At least this response demonstrates one real effect from fiscal policy! 


\section{References}

Bailey, M.J. (1962). National Income and the Price Level, New York, McGraw Hill.

Barro, R.J. (1974). "Are Government Bonds Net Wealth?," Journal of Political Economy, 82 (November/December), 1095-1118.

Barro, R.J. (1976). "Reply to Feldstein and Buchanan," Journal of Political Economy, 84 (April), 343-349.

Barro, R.J. (1977). "Unanticipated Money Growth and Unemployment in the United States," American Economic Review, 67 (March), 101-115.

Barro, R.J. (1979). "On the Determination of the Public Debt," Journal of Political Economy, 87, (October), 940-971.

Barro, R.J. (1989). "The Ricardian Approach to Budget Deficits," Journal of Economic Perspectives, 3 (Spring), 37-54.

Barro, R.J. (1995). "Optimal Debt Management," National Bureau of Economic Research, working paper no. 5327, October.

Barro, R.J. and D.B. Gordon (1983). "A Positive Theory of Monetary Policy in a Natural-Rate Model," Journal of Political Economy, 91 (August), 589-610.

Becker, G.S. (1974). "A Theory of Social Interactions," Journal of Political Economy, 82 (November/December), 1063-1093.

Bohn, H. (1990). "Tax Smoothing with Financial Instruments," American Economic Review, 80 (December), 1217-1230.

Buchanan, J.M. (1976). "Barro on the Ricardian Equivalence Theorem," Journal of Political Economy, 84 (April), 337-342.

Diamond, P.A. (1965). "National Debt in a Neoclassical Growth Model," American Economic Review, 55 (December), 1126-1150. 
Feldstein, M.S. (1976). "Perceived Wealth in Bonds and Social Security: A Comment," Journal of Political Economy, 84 (April), 331-336.

Gonner, E.C.K. (1923). Ricardo's Economic Essays, London, G. Bell and Sons.

Hakes, D.R. and K. McCormick (1995). "Did Smith Understand Ricardian Equivalence Before Ricardo?," unpublished, University of Northern Iowa, April.

Hall, R.E. (1990). "The Allocation of Wealth Among the Generations of a Family which Lasts Forever: A Theory of Inheritance," in R.E. Hall, The Rational Consumer, Cambridge MA, MIT Press.

Judd, K.L. (1991). "Optimal Taxation in Dynamic Stochastic Economies: Theory and Evidence," unpublished, Hoover Institution, Stanford University, January.

Lucas, R.E. and N.L. Stokey (1983). "Optimal Fiscal and Monetary Policy in an Economy without Capital," Journal of Monetary Economics, 12 (July), 55-93.

McCulloch, J.R. (1846). The Works of David Ricardo, London, John Murray.

Miller, M.H. and C.W. Upton (1974). Macroeconomics: A Neoclassical Introduction, Homewood IL, Irwin.

Modigliani, F. and M.H. Miller (1958). "The Cost of Capital, Corporation Finance and the Theory of Investment," American Economic Review, 48 (June), 261-297.

O'Driscoll, G.P. (1977). "The Ricardian Nonequivalence Theorem," Journal of Political Economy, 85 (February), 207-210.

Pigou, A.C. (1928). A Study in Public Finance, London, Macmillan.

Ricardo, D. (1951a). On the Principles of Political Economy and Taxation, 3rd edition, reprinted in P. Sraffa, ed., The Works and Correspondence of David Ricardo, v. I, Cambridge, Cambridge University Press.

Ricardo, D. (1951b). Funding System, reprinted in P. Sraffa, ed., The Works and Correspondence of David Ricardo, v. IV, Cambridge, Cambridge University Press. 
Samuelson, P.A. (1958). "An Exact Consumption-Loan Model of Interest with or without the Social Contrivance of Money," Journal of Political Economy, 66 (December), $467-482$.

Say, J.B. (1821). A Treatise on Political Economy, translated from 4th edition of the French, London, Longman, Hurst, Rees, Orme, and Brown.

Smith, A. (1791). An Inquiry into the Nature and Causes of the Wealth of Nations, 6th edition, London, A. Strahan and T. Cadell.

Tobin, J. (1971). "Asset Holdings and Spending Decisions," in J. Tobin, Essays in Economics, v.1, Macroeconomics, Amsterdam, North-Holland. 